\title{
Kewenangan Pengadilan Negeri Jakarta Pusat Dalam Pembatalan Putusan Arbitrase Di Janewa Swiss (Studi Kasus PT. Pertamina dan PT. PLN melawan Karaha Bodas Company)
}

\author{
Ircham Suryo Nugroho \\ Lembaga Bantuan Hukum Aksa Bumi \\ Jln. Sidikan No. 62, Sorosutan, Umbulharjo, Yogyakarta Indonesia \\ irchamsuryonugroho@gmail.com
}

\begin{abstract}
This research examines how the competence/authority of the Central Jakarta District Court in rejecting the arbitration award in Geneva, Switzerland which is final, binding and enforceable in resolving business disputes of PT. Pertamina and PT. PLN against Karaha Bodas Company. This paper uses normative legal research. The result of this research is that international arbitration decisions are final and binding on the parties. Two legal remedies may still be made against this decision, namely the rejection and cancellation of the implementation of foreign arbitration. The emergence of two legal remedies for annulment of the Geneva arbitration award in both the Swiss Federal Court and the Central Jakarta District Court has caused a lot of debate on which court is authorized to annul the Geneva arbitration award. With the appointment of Geneva as the place of arbitration (the arbitration seat) and the law underlying the arbitration dispute settlement (Lex Arbitri), the Swiss Federal Court has the authority to annul the Geneva arbitration award. Thus, the Central Jakarta District Court has no competence to reject the Geneva arbitration award.
\end{abstract}

Key Words: Annulment; district court; international arbitration award

\begin{abstract}
Abstrak
Penelitian ini mengkaji bagaimana kompetensi/kewenangan Pengadilan Negeri Jakarta Pusat dalam membatalkan putusan arbitrase di Jenewa, Swiss yang bersifat final, mengikat dan dapat dijalankan dalam penyelesaian sengketa bisnis PT. Pertamina dan PT. PLN melawan Karaha Bodas Company?. Tulisan ini menggunakan penelitian hukum normatif. Hasil dari penelitian ini yaitu putusan arbitrase internasional bersifat final dan mengikat para pihak. Terhadap putusan ini masih dapat dimungkinkan dilakukan dua upaya hukum yaitu penolakan dan pembatalan pelaksanaan arbitrase asing. Munculnya dua upaya hukum pembatalan putusan arbitrase Jenewa baik di Swiss Federal Court dan Pengadilan Negeri Jakarta Pusat menimbulkan banyak perdebatan mengenai pengadilan mana yang berwenang dalam pembatalan putusan arbitrase Jenewa. Dengan ditunjuknya Jenewa sebagai place of arbitration (seat) dan hukum yang mendasari penyelesaian sengketa arbitrase (Lex Arbitri), maka yang berwenang untuk membatalkan putusan arbitrase Jenewa adalah Swiss Federal Court. Dengan demikian, Pengadilan Negeri Jakarta Pusat tidak berwenang untuk mengadili upaya pembatalan putusan arbitrase Jenewa.
\end{abstract}

Kata-kata Kunci: Putusan arbitrase internasional; pembatalan; pengadilan negeri 


\section{Pendahuluan}

Kemakmuran ekonomi di banyak negara secara luas tergantung kepada perdagangan internasional. Pada 2006, sebagai contoh, 57\% produksi domestik kotor (GDP) di Belanda dan 53\% GDP di Afrika Selatan tergantung pada perdagangan internasional. Peningkatan kemakmuran di Cina dan India jelas merupakan akibat dari peningkatan besar-besaran atas ekspor mereka. Dalam hal ini telah terjadi konsensus yang luas di antara para ahli ekonomi dan pembuatan kebijakan bahwa ekonomi global secara umum, dan perdagangan internasional secara khusus, menawarkan sebuah kesempatan yang belum pernah ada sebelumnya untuk mendorong perkembangan ekonomi dan mengurangi secara signifikan kemiskinan di seluruh dunia. ${ }^{1}$

Salah satu bidang yang saat ini cukup berkembang adalah bidang perdagangan bebas (free trade), termasuk perdagangan bebas antara negaranegara dunia ini, dimana secara prinsip perdagangan bebas ini diakui sebagai suatu solusi terbaik dan adil bagi berjalannya roda perekonomian dunia. ${ }^{2}$ Semula, sebelum masalah kebebasan dalam perdagangan ini digalakan. Masing-masing negara saling memproteksi diri dan saling hanya menguntungkan negaranya sendiri saja. Mereka saling memproteksi dan negara yang satu berdagang dengan merugikan negara lain.

Kesadaran universal dari negara-negara di dunia dalam bidang perdagangan internasional sekarang ini adalah cenderung untuk memberlakukan perdagangan bebas, yang sering disebut dengan istilah "free trade" atau "trade liberalization". Ini fakta sudah tidak terbantahkan. Dan itu pulalah sebabnya mengapa keberadaan General Agreement on Tariffs and Trade (GATT) maupun World Trade Organization (WTO) dengan berbagai alasannya telah mendapat dukungan dari hampir semua negara di dunia ini. ${ }^{3}$

Sistem perdagangan modern menuju ke sistem perdagangan bebas. Bahkan menurut ekonom klasik-Adam Smith- bahwa perdagangan barang-barang mestilah dibiarkan bebas berdasarkan hukum pasar, yang populer dengan istilah laissez faire, yang secara harafiah berarti "bebas melakukan apa yang engkau inginkan". Yakni bebas dari campur tangan pemerintah untuk membantu orang miskin, pengontrolan upah buruh, bantuan atau subsidi pertanian, dan mendukung adanya free trade. ${ }^{4}$

1 Peter van den Bossche, Pengantar Hukum WTO (World Trade Organization), Yayasan Obor Indonesia, Jakarta, 2010, hlm. 1.

${ }^{2}$ Munir Fuady, Hukum Dagang Internasional (Aspek Hukum dari WTO), Citra Aditya Bakti, Bandung, 2004, hlm. 1.

IIbid., hlm. 2-3.

${ }^{4}$ Ibid. 
Hubungan-hubungan internasional yang diadakan antar negara, negara dengan individu, atau negara dengan organisasi internasional tidak selamanya terjalin dengan baik. Acap kali hubungan itu menimbulkan sengketa di antara mereka. Sengketa dapat bermula dari berbagai sumber potensi sengketa antarnegara dapat berupa perbatasan, sumber daya alam, kerusakan lingkungan, perdagangan, dan lain-lain. Manakala hal demikian itu terjadi, hukum internasional memainkan peran yang tidak kecil dalam penyelesaiannya. ${ }^{5}$

Hubungan-hubungan internasional yang diadakan oleh subjek hukum internasional selalu ada kemungkinan munculnya sengketa di kemudian hari. Sengketa bisa saja muncul terkait perbatasan, perdagangan, dan lain-lain. Di dalam menyelesaikan sengketa ada beberapa cara yang bisa dipilih, yaitu melalui negosiasi, mediasi, pengadilan, dan arbitrase. Sebagai salah satu alternatif penyelesaian sengketa, arbitrase dpandang sebagai cara yang efektif dan adil. Badan arbitrase akan berfungsi apabila para pihak sepakat untuk menyerahkan sengketa kepadanya baik sebelum sengketa muncul maupun setelah sengketa muncul. ${ }^{6}$

Arbitrase menjadi suatu wadah penyelesaian sengketa yang paling digemari para pelaku bisnis. Arbitrase internasional telah banyak dipakai oleh para pelaku bisnis yang notabene sering terkait dengan kasus-kasus ekonomi, utamanya perdagangan dengan nominal angka yang dipersengketakan cukup mencengangkan bagi orang pada umumnya. Arbitrase sebagai bentuk pewasitan di bidang proses peradilan di luar peradilan umum merupakan sarana yang sangat membantu menyelesaikan perselisihan-perselisihan atau sengketa yang terjadi dalam pelaksanaan perjanjian atau kontrak, khusus dalam hukum privat baik yang bersifat nasional maupun yang bersifat internasional, seperti dalam pelaksanaan perjanjian niaga atau perjanjian komersial dan perjanjian investasi (penanaman modal). ${ }^{7}$

Ketika para pihak dalam sebuah perjanjian sepakat bahwa mereka terikat pada klausula arbitrase, maka lembaga pengadilan tidak berwenang lagi untuk mengadili sengketa tersebut. Namun, pengadilan juga mempunyai peranan penting bagi institusi arbitrase agar putusan yang telah dihasilkan dapat berjalan efektif. Campur tangan pengadilan tersebut juga dijelaskan oleh Konvensi New York 1958 bahwa the Court of Contracting State, when seized of an action in a matter in respect of which the parties have made an agreement within the meaning of this article,

${ }^{5}$ Huala Adolf, Hukum Penyelesaian Sengketa Internasional, Cetakan Pertama, Sinar Grafika, Jakarta, tt, hlm.1.

6 Muhammad Asri, http://www.anaksmanda.com/PENYELESAIAN SENGKETA/arbitraseinternasional.html, diakses pada tanggal 10 Agustus 2017, pukul 21.47.

7 Akhmad Ichsan, Kompedium Tentang Arbitrase Perdagangan Internasional (Luar Negeri), Cetakan Pertama, Pradnya Paramita, Jakarta, tt, hlm. 1. 
shall, at the request of one of the parties, refer the parties to arbitration, unless it finds that the said agreement is null and void, inoperative or incapable of being performed. 8

Kasus cukup menarik yang menyita perhatian masyarakat internasional yaitu kasus antara Pertamina Vs Karaha Bodas Corporation (KBC). Kasus ini diselesaikan melalui arbitrase internasional di Jenewa dan Arbitrase Jenewa membuat putusan agar Pertamina dan PLN membayar ganti rugi kepada KBC. Pertamina melakukan upaya hukum pembatalan putusan arbitrase ini di Pengadilan di Swiss, tapi ditolak karena tidak dibayarkan uang deposit sebagaimana disyaratkan oleh Court. Kemudian Pertamina melakukan upaya hukum kembali untuk pembatalan putusan arbitrase tersebut dengan mengajukan ke Pengadilan Negeri Jakarta Pusat. Dalam putusannya nomor 86/PN/Jkt.Pst/2002, 9 September 2002, pengadilan Negeri Jakarta Pusat akhirnya mengabulkan gugatan Pertamina dengan membatalkan putusan arbitrase internasional, UNCITRAL, di Jenewa, Swiss. Adapun beberapa alasannya antara lain pengangkatan arbiter tidak dilakukan seperti yang telah diperjanjikan dan tidak diangkat arbiter yang telah dikehendaki oleh para pihak berdasarkan perjanjian, sementara Pertamina tidak diberikan proper notice mengenai arbitrase ini dan tidak diberi kesempatan untuk membela diri. Majelis arbitrase telah salah menafsirkan force majeure, sehingga mestinya Pertamina tidak dapat dimintakan pertanggungjawab atas sesuatu yang di luar kemampuannya. Di samping itu, Majelis Arbitrase dianggap telah melampaui wewenangnya karena tidak menggunakan hukum Indonesia, padahal hukum Indonesia adalah yang harus dipakai menurut kesepakatan para pihak, Majelis arbitrase hanya menggunakan hati nuraninya sendiri berdasarkan pertimbangan ex aequeo et bono. ${ }^{9}$

Kasus ini menarik dan memunculkan debatable di antara para ahli hukum, yaitu apakah benar Pengadilan Negeri Jakarta Pusat berwenang untuk membatalkan putusan arbitrase Jenewa? Oleh karena itu, penulis tertarik untuk mencoba menganalis kompetensi/wewenang Pengadilan Negeri di dalam mekanisme pelaksanaan keputusan arbitrase internasional baik melalui pembatalan maupun penolakan.

\section{Rumusan Masalah}

Berdasarkan latar belakang diatas, penulis merumuskan masalah sebagai berikut. Bagaimana kompetensi/kewenangan Pengadilan Negeri Jakarta Pusat

${ }^{8}$ Dodik Setiawan Nur Heriyanto, Pembatalan Keputusan Arbitrase Internasional Oleh Pengadilan Negeri (Studi Kasus Pembatalan Keputusan Arbitrase Jenewa oleh Pengadilan Jakarta Pusat), Warta Hukum Edisi Juli-Agustus 2009, Pusdiklat FH UII, Yogyakarta, hlm. 4. Lihat Convention on the Recognition and Enforcement of Foreign Arbitral Awards, 10 Juni 1958, 330 U.N.T.S. 38, psl.II(3) (selanjutnya Konvensi New York 1958). Dodik Setiawan Nur Heriyanto, "Strengthening Indonesian Judges Understanding of the Refusal and Annulment Grounds of Foreign Arbitral Awards", Acta Juridica Hungarica, Vol. 56, 2015, hlm. 169.

${ }_{9}^{9}$ Muhammad Asri, Log. Cit. 
dalam membatalkan putusan arbitrase di Jenewa, Swiss yang bersifat final, mengikat dan dapat dijalankan dalam penyelesaian sengketa bisnis PT. Pertamina dan PT. PLN melawan Karaha Bodas Company?

\section{Tujuan Penelitian}

Penelitian ini bertujuan untuk mengetahui kewenangan Pengadilan Negeri Jakarta Pusat dalam membatalkan putusan arbitrase internasional di Jenewa Swiss yang bersifat final, mengikat dan dapat di jalankan dalam sengketa bisnis PT. Pertamina dan PT. PLN melawan Karaha Bodas Company.

\section{Metode Penelitian}

Jenis penelitian ini adalah normatif karena yang dikaji adalah kewenangan Pengadilan Negeri Jakarta Pusat dalam membatalkan Putusan Arbitrase Internasional di Jenewa Swiss dalam sengketa bisnis PT. Pertamina dan PT. PLN melawan Karaha Bodas Company, ditinjau dari Undang-Undang Nomor 30 Tahun 1999 tentang Arbitrase dan Alternatif Penyelesaian Sengketa. Bahan hukum yang digunakan adalah bahan hukum primer dan sekunder. Bahan hukum primer yaitu Kitab Undang-Undang Hukum Perdata, Undang-Undang Nomor 30 Tahun 1999 tentang Arbitrase dan Alternatif Penyelesaian Sengketa, Keputusan Presiden No. 34 Tahun 1981 Convention on the Recognition and Enforcement of Foreign Arbitral Awards, 10 Juni 1958, 330 U.N.T.S. 38., psl.II (3). Kemudian data sekunder meliputi buku, jurnal nasional dan internasional yang berkaitan dengan penelitian ini, karya ilmiah, surat kabar dan media elektronik yang relevan dengan penelitian ini. Pendekatan yang yang digunakan dalam penelitian ini adalah pendekatan Perundang-undangan (Statute Approach) dan kasus (case) hal ini dimaksudkan bahwa peneliti menggunakan peraturan perundang-undangan sebagai dasar awal melakukan analisis terhadap kasus pembatalan putusan arbitrase internasional di Jenewa Swiss antara PT. Pertamina dan PT. PLN melawan Karaha Bodas Company. Pengolahan dan penyajian data penelitian ini dengan cara pengumpulan data dalam penelitian ini terlebih dahulu, setelah itu penulis melakukan pengumpulan data sekunder yang ada relevansinya dengan pokok permasalahan yang menjadi kajian dalam penelitian ini. Setelah semua bahan terkumpul, maka langkah selanjutnya adalah memetakan bahan-bahan hukum tersebut ssesuai dengan pokok permasalahan. 


\section{Hasil Penelitian dan Pembahasan}

Salah satu bidang yang saat ini cukup berkembang adalah bidang perdagangan bebas (free trade), termasuk perdagangan bebas antara negaranegara dunia ini, dimana secara prinsip perdagangan bebas ini diakui sebagai suatu solusi terbaik dan adil bagi berjalannya roda perekonomian dunia. ${ }^{10}$

Perekonomian suatu negara berhubungan dengan dan dipengaruhi oleh perekonomian Negara lain. Hubungan ini meliputi transaksi ekonomi berupa perdagangan barang-barang, jasa-jasa dan sumber-sumber serta transaksi investasi penanaman modal dan transaksi finansial utang-piutang.

Menurut Munir Fuady, perdagangan bebas adalah suatu perdagangan antarnegara, baik yang berkenaan dengan impor maupun ekspor yang tidak dibatasbatasi atau diintervensi dengan pengenaan tariffs, kuota, subsidi, kontrol nilai tukar dan lain-lain batasan dan intervensi yang merupakan proteksi dan dapat menghambat arus perdagangan, di mana dengan perdagangan bebas tersebut, pertukaran antara permintaan dan penawaran barang atau jasa menjadi bebas tanpa diatur-atur, hal mana dapat mengakibatkan areal untuk masing-masing negara sesuai dengan sumber daya yang tersedia di negara yang bersangkutan, yang dapat menimbulkan keuntungan komparatif, dan pada gilirannya akan menimbulkan iklim perdagangan yang lebih produktif dan efisien. ${ }^{11}$

Untuk menjamin bahwa kesempatan untuk mendorong perkembanagn ekonomi dan mengurangi secara signifikan kemiskinan di seluruh dunia, globalisasi ekonomi dan perdagangan internasional harus dikelola dan diatur pada tataran internasional. Jika tidak, globalisasi ekonomi dan perdagangan internasional akan menimbulkan ketidakseimbangan ekonomi, ketidakadilan sosial, kerusakan lingkungan, dan lunturnya kebudayaan yang lebih parah. ${ }^{12}$

Negara-negara maju maupun negara berkembang memerlukan peraturan internasional untuk:13

a. Menghentikan tindakan-tindakan penghambat perdagangan dalam situasi prosedur-prosedur tersebut tidak diperlukan dan juga tidak diinginkan, tetapi tetap diterapkan dikarenakan tekanan dari kelompok-kelompok tertentu yang terorganisasi dengan baik

b. Memberikan keamanan dan kepastian kepada pedagang-pedagang sehubungan peraturan-peraturan nasional yang diterapkan kepada perdagangan internasional atas barang dan jasa mereka

c. Menjamin nilai-nilai sosial dan kepentingan lainnya, seperti kesehtan masyarakat, lingkungan, keamanan konsumen, standar-standar

\footnotetext{
${ }^{10}$ Munir Fuady, .Log. Cit.

11 Ibid., hlm. 3.

12 Peter van den Bossche, Log. Cit.

${ }^{13}$ Ibid.
} 
pembayaran upah minimum, pengembangan ekonomi dan moral masyarakat, dapat dilindungi dan ditingkatkan secara sepadan.

Dalam konteks hukum perdagangan internasional banyak sekali masalah yang timbul akibat perdagangan itu sendiri. Dimana sebenarnya wilayah dari perdagangan internasional meliputi negara di belahan bumi utara dan selatan. Negara maju hampir mayoritas seluruhnya merupakan negara di wilayah utara seperti Merika, Inggris, Rusia, Italia dan lain sebagainya. Sedangkan di wilayah selatan, mayoritas negara berkembang seprti Afrika selatan, India, Indonesia dan lain sebagainya.

Di wilayah selatan banyak negara yang memiliki Sumber Daya Alam yang melimpah tetapi tidak maksimal dalam pengolahannya. Oleh sebab itu hubungan Internasional harus dijalin antara negara maju dan berkembang. Negara maju memiliki Sumber Daya Manusia yang baik dan handal dalam menciptakan inovasi dalam pengolahan Sumber Daya Alam tersebut.

Untuk mewujudkan perdagangan internasional seperti yang telah dibahas di atas negara yang maju selalu menawarkan barang dan/atau jasa kepada negara berkembang. Karea negara berkembang memang belum sepenuhnya dapat memproduksi sendiri barang barang yang harus di sediakan dalam kehidupan sehari-hari. Seperti contohnya adalah minyak. Di Indonesia sendiri minyak mentah sangat banyak terkandung di perut bumi Indonesia. Akan tetapi kurangnya teknologi dalam hal pengolahan minyak bumi menjadi bahan bakar minyak membuat Indonesia melakukan hubungan bilateral dengan Amerika yaitu PT. Karaha Bodas Company.

Dalam perjalanannya telah terjadi sengketa bisnis dimana penyelesaiannya melalui arbitrase Internasional. Penyelesaian sengketa bisnis melalui arbitrase ini sangatlah di gemari oleh pengusaha ataupun tingkat negara.

Penyelesaian sengketa dapat dibedakan antara penyelesaian sengketa secara damai dan penyelesaian sengketa secara adversial. Penyelesaian sengketa secara damai lebih dikenal dengan penyelesaian secara musyawarah mufakat. Sementara penyelesaian secara adversarial lebih dikenal dengan penyelesaian sengketa oleh pihak ketiga yang tidak terlibat dalam sengketa. Arbitrase merupakan institusi penyelesaian sengketa yang menggunakan pendekatan pertentangan (adverserial) dengan hasil win lose yang dipilih sebagai alternatif oleh pelaku bisnis.

Kata arbitrase menurut Subekti berasal dari bahasa Latin ar bi tr ar e yang artinya kekuasaan untuk menyelesaikan sesuatu menurut "kebijaksanaan". Dikaitkannya istilah arbitrase dengan kebijaksanaan seolah-olah memberi 
petunjuk bahwa majelis arbitrase tidak perlu memerhatikan hukum dalam menyelesaikan sengketa para pihak, tetapi cukup mendasarkan pada kebijaksanaan. Pandangan tersebut keliru karena arbiter juga menerapkan hukum seperti apa yang dilakukan oleh hakim di pengadilan. ${ }^{14}$

Menurut Munir Fuady, secara teknis merujuk pada orang yang menyelesaikan sengketa di mana arbitrase merupakan suatu metode penyelesaian sengketa yang sering juga disebut dengan pengadilan wasit. Sehingga para "arbiter" dalam peradilan arbitrase berfungsi memang layaknya seorang "wasit" (referee). 15

Arbitrase menurut Pasal 1 angka 1 Undang Undang Nomor 30 Tahun 1999 adalah cara penyelesaian suatu sengketa perdata di luar pengadilan umum yang didasarkan pada Perjanjian Arbitrase yang dibuat secara tertulis oleh para pihak yang bersengketa. Black's Law Dictionary memberikan pengertian "Arbitration. an arrangement for taking an abiding by the judgment of selected persons in some disputed matter, instead of carrying it to establish tribunals of justice, and is intended to avoid the formalities, the delay, the expense and vexation of ordinary litigation".16

Dari pengertian itu terdapat tiga hal yang harus dipenuhi, yaitu: adanya suatu sengketa; kesepakatan untuk menyerahkan ke pihak ketiga; dan putusan final dan mengikat akan dijatuhkan. Dan dari pengertian Pasal 1 butir 1 tersebut diketahui pula bahwa dasar dari arbitrase adalah perjanjian di antara para pihak sendiri, yang didasarkan pada asas kebebasan berkontrak. Hal ini sesuai dengan ketentuan dalam Pasal 1338 KUHPerdata, yang menyatakan bahwa apa yang telah diperjanjikan oleh para pihak mengikat mereka sebagai undang-undang.

Arbitrase adalah penyerahan sengketa secara sukarela kepada pihak ketiga yang netral yang mengeluarkan putusan bersifat final dan mengikat (binding). Badan arbitrase dewasa ini sudah semakin populer dan semakin banyak digunakan dalam menyelesaikan sengketa-sengketa internasional. ${ }^{17}$ Arbitrase adalah salah satu cara atau alternatif penyelesaian sengketa yang telah dikenal lama dalam hukum internasional. ${ }^{18}$ Arbitrase internasional mempunyai perbedaan dengan arbitrase nasional, dan umumnya arbitrase internasional harus mengandung unsur asing diantara para pihak sebagai salah satu persyaratannya. ${ }^{19}$

Menurut Huala Adolf, batasan mengenai badan arbitrase internasional publik ini adalah "Suatu alternatif penyelesaian sengketa melalui pihak ketiga (badan arbitrase) yang ditunjuk dan disepakati para pihak (negara) secara

${ }^{14}$ Subekti, Kitab Undang-Undang Hukum Perdata, Pradnya Paramita, Jakarta. 1981, hlm. 1.

${ }^{15}$ Munir Fuady, Arbitrase (Alternatif Penyelesaian Sengketa Bisnis), Citra Aditya Bakti, Bandung, 2000, hlm. 12.

${ }^{16}$ Muhammad Asri, Log. Cit.

${ }^{17}$ Huala Adolf, Op. Cit., hlm. 23.

${ }^{18} \mathrm{Ibid}$.

19 Sunarjati Hartono, Beberapa Masalah Transnasional dalam Penanaman Modal Asing di Indonesia, Cet.ke-1, Binacipta, Bandung, 1972, hlm. 204-205. 
sukarela untuk memutus sengketa yang bukan bersifat perdata dan putusannya bersifat final dan mengikat." 20

Arbitrase internasional dapat pula diberikan pengertian, yaitu arbitrase yang ruang lingkup keberadaan dan yurisdiksinya bersifat internasional. Suatu arbitrase dianggap internasional apabila para pihak pada saat dibuatnya perjanjian yang bersangkutan mempunyai tempat usaha mereka (place of business) di negara-negara berbeda. Misalnya salah satu pihak memiliki tempat usaha di Amerika, dan pihak lain memiliki tempat usaha di Indonesia. Jika terjadi perselisihan di antara mereka, dan mereka memilih cara penyelesaian melalui arbitrase, maka arbitrase ini tergolong arbitrase internasional. ${ }^{21}$

Badan arbitrase baru aakan berfungsi apabila ada kesepakatan dan penunjukan dari para pihak. Kesepakatan para pihak pulalah yang akan menentukan kompetensi atau yurisdiksi badan peradilan arbitrase. Tujuan dan masalah atau sengketa yang harus diselesaikan atau diputus badan arbitrase juga ditentukan oleh para pihak. Penunjukan dan kompetensi arbitrase biasanya dituangkan dalam akta kompromi dan kesepakatan atau perjanjian para pihak yang ditentukan kemudian. ${ }^{22}$

The United Nations on Arbitral Procedure mengusulkan negara-negara untuk menyerahkan sengketanya kepada Mahkamah Internasional atau kepada the Permanent Court of Arbitration (Pasal 3 ayat (1 dan 3) menyatakan apabila para pihak telah menunjuk suatu badan peradilan,apakah Mahkamah Internasional atau arbitrase maka badan peradilan yang disebut itulah yang memilki kompetensi untuk menangani dan memutuskan sengketa. ${ }^{23}$

Putusan arbitrase umumnya mengikat para pihak, penataan terhadapnya dipandang tinggi, dan biasaanya putusannya bersifat final dan mengikat. Putusan arbitrase kerap disepakati sebagai putusan yang terakhir dan mengikat (final and binding).

Sesuai aturan pada umumnya, putusan arbitrase, baik putusan yang berasal dari badan arbitrase domestik maupun internasional, bersifat hukum tetap/final dan mengikat. ${ }^{24}$ Dan Konvensi New York 1958 juga secara jelas mewajibkan negara-negara anggota yang terikat konvensi tersebut untuk mengakui (recognize)

\footnotetext{
${ }^{20}$ Huala Adolf, Op. Cit., hlm. 40.

${ }^{21}$ Ibid.

22 Ibid., hlm. 51.

${ }^{23}$ Ibid.

${ }^{24}$ UU No. 30 Tahun 1999, psl.60; Keputusan Presiden No.34 Tahun 1981, State Gazzete Tahun 1981
} No. 20 tanggal 5 Agustus 1981. 
putusan arbitrase sebagai putusan yang mengikat dan berlaku bagi mereka. ${ }^{25}$ Para pihak yang terkait diwajibkan melaksanakan putusan yang telah dikeluarkan oleh badan arbitrase yang menjadi rujukan sengketa. Kalau tidak melaksanakan putusan tersebut maka akan dianggap cidera janji (wanprestasi).

Putusan arbitrase tidak bisa dimintakan banding atau kasasi. Penegasan ini bemakna pengadilan tidak berwenang lagi untuk mempermasalahkan materi putusan. Tugas pokok pengadilan dalam menjalankan fungsi eksekutor, hanya meneliti apakah ada pelanggaran atas asas-asas yang dilarang dan aturan formal yang bersifat mendasar.

Setelah putusan dibuat dan dibacakan pihak yang dikalahkan dapat melakukan dua upaya hukum. Dua upaya hukum ini tidak sama dengan upaya banding di pengadilan. Putusan arbitrase menurut sifatnya, dan kesepakatan para pihak dalam kontrak pada umumnya, tidak dibuka kemungkinan untuk dilakukan banding.

Pertama, upaya hukum berupa penolakan pelaksanaan atau eksekusi (enforcement) atas Putusan Arbitrase Internasional kepada pengadilan dimana aset atau barang berada. Hal ini terjadi mengingat putusan arbitrase dibuat di suatu negara tetapi pelaksanaanya dilakukan di negara lain. Putusan arbitrase Internasional pada umumnya memilki karakter demikian: pelaksanaan putusan akan sangat bergantung pada dimana aset atau barang yang hendak dieksekusi berada. Perlibatan pengadilan tidak dapat dihindari mengingat pemaksaan atas putusannya hanya bisa dilakukan oleh pengadilan dalam bentuk penetapan eksekusi. ${ }^{26}$

Alasan permohonan penolakan pengakuan dan pemberian exequatur putusan arbitrase asing, disebut secara "limitative" dalam Pasal V ayat (2) Konvensi New York 1958. Ada sebanyak lima alasan yang dapat dijadikan sebagai dasar permohonan penolakan dan alasan-alasan tersebut bersifat "alternative", yakni: 27

1. Perjanjian Arbitrase tidak sah

2. Tidak memperoleh kesempatan melakukan pembelaan

3. Putusan tidak sesuai dengan penugasan

4. Susunan atau penunjukan arbiter tidak sesuai dengan kesepakatan yang dijanjikan para pihak.

5. Putusan belum mengikat bagi para pihak

${ }^{25}$ Konvensi New York 1958, psl. III.

${ }^{26} \mathrm{Ibid}$.

27 M. Yahya Harahap, Arbitrase ditinjau dari Reglemen Acara Perdata (Rv), Peraturan Prosedur BANI, International Centre for the Settlement of Investment Disputes (ICSID), UNCITRAL Arbitration Rules, Convention on the Recognition and Enforcement of Foreign Arbitral Award, dan Perma No. 1 Tabun 1990, Edisi Kedua, Sinar Grafika, Jakarta, 2006, hlm. 355-368; 
Kedua, pihak yang dikalahkan dapat "memasalahkan" Putusan Arbitrase Internasional yang telah dibuatnya. Upaya hukum ini pada dasarnya untuk membatalkan putusan arbitrase. Dalam upaya hukum ini, sama seperti hukum pertama, memerlukan keterlibatan pengadilan. Pengadilan dianggap sebagai otoritas yang berwenag untuk membatalkan putusan. ${ }^{28}$

Perbedaan mendasar kedua upaya hukum tersebut adalah proses dan alasan pembatalan putusan arbitrase diatur dalam peraturan perundang-undangan suatu negara dan tidak diatur dalam sebuah perjanjian internasional. Sementara penolakan putusan arbitrase asing justru mendapat pengaturan dalam perjanjian internasional yang kemudian ditransformasikan dalam bentuk peraturan perundang-undangan nasional, yaitu New York Convention 1958..$^{29}$

Pembatalan putusan arbitrase berakibat pada dinafikannya (seolah tidak pernah dibuat) suatu putusan arbitrase. Terhadap putusan arbitrase yang dibatalkan, pengadilan dapat meminta agar para pihak mengulang proses arbitrase (re-arbitrate). Hanya saja pembatalan putusan arbitrase tidak membawa konsekuensi pada pengadilan yang membatalkan untuk memilki wewenang memeriksa dan memutus sengketa. Pabila hal itu dilakukan akan bertentangan dengan asas kebebasan berkontrak yang dimiliki para pihak dalam penyelesaian sengketa mereka. ${ }^{30}$

Dalam proses pembatalan pengadilan tidak berwenang untuk memeriksa pokok perkara yang dipersengketakan oleh para pihak. Kewenangan pengadilan hanya terbatas pada kewenangan untuk memeriksa keabsahan dari segi prosedur pengembalian putusan arbitrase, antara lain proses pemilihan para arbiter hingga pemberlakukan hukum yang dipilih oleh para pihak dalam penyelesaian sengketa. Alasan ini dan alasan lainnya sebagai dasar pembatalan putusan arbitrase lazimnya diatur dalam hukum arbitrase dari suatu negara. ${ }^{31}$

Penolakan putusan arbitrase oleh pengadilan tidak berarti menafikan putusan tersebut. Penolakan mempunyai konsekuensi tidak dapatnya putusan arbitrase dilaksanakan di yurisdiksi pengadilan yang menolaknya. Apabila ternyata di negara lain terdapat aset dari para pihak yang dikalahkan, pihak yang dimenangkan masih dapat meminta eksekusi di pengadilan negera tersebut. ${ }^{32}$

UU Arbitrase mengatur bagaimana jika suatu putusan arbitrase internasional dieksekusi di Indonesia, eksekusi harus sesuai dengan Keppres Nomor 34 Tahun 1981 yang mengesahkan Convention on the Recognition and

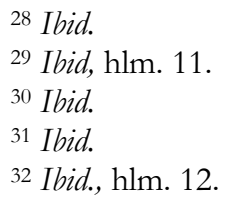


Enforcement of Foreign Arbital Award atau yang dikenal dengan New York Convention 1958, merupakan penyesuaian terhadap aturan mengenai pengakuan Keputusan Arbitrase Asing yang telah berlaku secara internasional menggantikan Konvensi Jenewa 1927 yang telah dianggap tidak sesuai. ${ }^{33}$

Dalam pelaksanaannya di Indonesia ternyata membutukkan adanya Peraturan Pelaksanaan, hingga munculah Peraturan Mahkamah Agung (PERMA) Nomor 1 Tahun 1990 tentang Tata Cara Pelaksanaan Putusan Arbitrase Asing. Sejak saat itu baru keputusan arbitrase asing dapat dilaksanakan di Indonesia sejak adanya Keppres Nomor 34 Tahun 1981 hakimhakim Indonesia telah terikat untuk melaksanakan keputusan arbitrase luar negeri yang memang sudah mempunyai status "dapat dijalankan" (enforceble) ini sepanjang keputusan arbitrase yang bersangkutan telah dibuat di negara juga peserta konvensi ini. Menurut Sudargo Gautama, jika hakim Indonesia menolak pelaksanaan keputusan arbitrase dagang luar negeri dari negara yang juga turut menjadi peserta konvensi PBB 1958 tentang Pengakuan dan Pelaksanaan Keputusan Arbitrase Asing, maka dapat saja dianggap telah melakukan suatu International Wrong. Sehingga dengan itu tidak perlu adanya peraturan pelaksanaan lebih lanjut. ${ }^{34}$

Dalam artikel ini, penulis menggunakan kasus Karaha Bodas v. Pertamina. Karena kasus ini sangat menarik untuk dikaji, terlebih pada keputusan arbitrase internasional pada kasus ini yang dibatalkan oleh Pengadilan Negeri Jakarta Pusat. Kronologi kasus ini adalah sebagai berikut:

Kasus antara Karaha Bodas Company v. Perusahaan Minyak dan Gas Bumi Negara (Pertamina) ini mengejutkan masyarakat internasional tatkala Pengadilan Negeri Jakarta Pusat membatalkan putusan arbitrase yang dibuat di Jenewa, Swiss (Geneva Arbitral Award, Switzerland). Arbitrase Jenewa memutuskan agar Pertamina membayar ganti rugi sebesar 261.000.000 US\$ kepada Karaha Bodas Company sebagai kompensasi atas penundaan proyek pembangunan energi listrik 1998. Atas putusan arbitrase Jenewa, Pertamina tidak bersedia secara sukarela melaksanakannya. Sebagai upaya hukum, Pertamina telah meminta pengadilan di Swiss untuk membatalkan putusan arbitrase. Hanya saja upaya ini tidak dilanjutkan (dismiss) karena tidak dibayarnya uang deposit sebagaimana dipersyaratkan oleh Swiss Federal Supreme Court.

Sementara itu, KBC telah melakukan upaya hukum berupa permohonan untuk pelaksanaan Putusan Arbitrase Jenewa di pengadilan beberapa negara di mana asset dan barang Pertamina berada, kecuali di Indonesia. Pada 21 Februari

${ }^{33}$ Harry Katuuk, Kekalahan Pertamina vs Karaha Bodas CO Dalam Peradilan Arbitrase Internasional, pada http://www.google.com, diakses pada tanggal 10 Agustus 2017 pukul 19.00.

${ }^{34}$ Sudargo Gautama, Perkembangan Arbitrase Dagang Internasional di Indonesia, Eresco, Jakarta, 1989, hlm. 64. 
2001, KBC mengajukan permohonan pada US District Court for the Southern District of Texas untuk melaksanakan Putusan Arbitrase Jenewa. Selanjutnya KBC mengajukan permohonan yang sama pada pengadilan Singapura dan Hong Kong. Dalam menyikapi upaya hukum KBC, Pertamina melakukan upaya hukum berupa penolakan pelaksanaan di pengadilan-pengadilan yang diminta oleh KBC untuk melakukan eksekusi. Pertamina melanjutkan upaya hukum pembatalan putusan arbitrase Jenewa di pengadilan Indonesia. Pada 14 Maret 2002 Pertamina secara resmi mengajukan gugatan pembatalan Putusan Arbitrase Jenewa kepada PN Jakarta Pusat. Dalam putusannya nomor 86/PN/Jkt.Pst/2002, 9 September 2002, Pengadilan Negeri Jakarta Pusat akhirnya mengabulkan gugatan Pertamina dengan membatalkan putusan arbitrase internasional, UNCITRAL, di Jenewa, Swiss. ${ }^{35}$

Pada kasus di atas, yang menjadi persoalan adalah kewenangan pengadilan negeri untuk membatalkan putusan arbitrase internasional. Majelis Hakim berpendapat bahwa Majelis Hakim Arbitrase Jenewa telah melampaui kewenangannya karena tidak menggunakan hukum Indonesia seperti yang sudah tertuang dalam Joint Operation Contract (JOC) antara Pertamina dengan Karaha Bodas Company maupun Energy Sales Contract (ESC) antara Pertamina dan Perusahaan Listrik Negara. ${ }^{36}$

Putusan arbitrase Jenewa dalam sengketa antara KBC dan Pertamina sudah final, mengikat, dan mempunyai daya eksekutor setelah diputuskan di Jenewa, Swiss pada 18 Desember 2000. Akan tetapi pada suatu kondisi tertentu, sifat final and binding award dapat dikesampingkan dengan mengajukan gugatan pembatalan putusan arbitrase. Jika permohonan pembatalan tersebut diterima oleh pengadilan yang berwenang, maka sifat final and binding ini tidak akan melekat lagi pada putusan arbitrase Jenewa, dan akan dianggap tidak pernah ada. Namun jika putusan arbitrase ditolak (refused) oleh pengadilan yang berwenang, maka sifat final dan binding ini tetap melekat. Jadi penolakan yang telah dilakukan oleh Pengadilan Federal Swiss terhadap putusan arbitrase Jenewa antara KBC dan Pertamina, tidak akan menghilangkan sifat final and binding putusan ini. Putusan ini masih mengikat dan mempunyai kekuatan hukum tetap bagi para pihak yang bersengketa walaupun Pengadilan Swiss secara tegas menolak atas pembatalan putusan arbitrase Jenewa.

Berdasarkan Pasal 70 UU No. 30 Tahun 1999 menyatakan bahwa putusan arbitrase dapat diajukan permohonan pembatalan dengan alasan: (a) dokumen

\footnotetext{
35 Ibid.

36 Sudargo Gautama, Arbitrase Luar Negeri dan Pemakaian Hukum Indonesia, PT. Citra Adhitya Bakti,
} Bandung, 2004, hlm. $36 \& 127$. 
diakui palsu atau dinyatakan palsu; (b) dokumen disembunyikan oleh pihak lawan; atau (c) putusan diambil dari hasil tipu muslihat. 37 Pada penjelasan UU No. 30 Tahun 1999 khususnya Pasal 70 menjelaskan bahwa permohonan pembatalan hanya dapat diajukan terhadap putusan arbitrase yang sudah didaftarkan di Pengadilan, alasan-alasan permohonan pembatalan yang disebut diajukan harus terlebih dahulu dibuktikan dengan Pengadilan. Apabila pengadilan menyertakan bahwa alasanalasan tersebut terbukti atau tidak terbukti, maka putusan pengadilan ini dapat digunakan sebagai dasar pertimbangan bagi hakim untuk mengabulkan atau menolak permohonan. ${ }^{38}$

Permohonan pembatalan diajukan secara tertulis dalam waktu 30 hari ${ }^{39}$ kepada Pengadilan wilayah hukum dimana keputusan arbitrase diambil, hal ini didasarkan pada syarat putusan arbitrase asing (internasional), yang apabila permohonan dikabulkan, maka dalam waktu 30 hari ketua Pengadilan Negeri akan menentukan lebih lanjut akibat pembatalan seluruhnya atau sebagian putusan arbitrase. ${ }^{40}$ Untuk memberikan kepastian hukum kepada pihak lawan, berdasarkan ketentuan Pasal 72 ayat (4) UU No. 30 Tahun 1999 dinyatakan bahwa terhadap putusan pembatalan dari Pengadilan Negeri dapat diajukan permohonan banding ke Mahkamah Agung yang memutus dalam tingkat pertama dan terakhir. Akan tetapi Undang-undang Arbitrase tidak mengatur tentang ketentuan mengenai batas waktu pengajuan banding dan memori banding, maka hal ini harus didasarkan kepada ketentuan hukum acara yang berlaku, yang menyatakan bahwa pengajuan memori banding oleh Pemohon Banding wajib disampaikan dalam tenggang waktu 14 hari setelah permohonan banding dicatat dalam buku daftar register. Sejak permohonan banding diterima paling lama tiga puluh hari kemudian sudah harus diputus.

Pasal 70, Pasal 71 dan Pasal 72 UU No. 30 Tahun 1999 hanya memberi wewenang kepada Pengadilan Indonesia untuk melakukan pembatalan Putusan Arbitrase yang dibuat di Indonesia. Hal ini dapat diartikan bahwa ketentuanketentuan pembatalan tersebut bukan sebagai dasar bagi Pengadilan Indonesia untuk melakukan pembatalan Putusan Arbitrase Internasional. Hal ini terlihat dari penggunaan kata Putusan Arbitrase Internasional dalam Pasal 65 sampai dengan Pasal 69 yang dibedakan dengan kata Putusan Arbitrase seperti tercantum dalam Pasal 70. Jadi Pengadilan Negeri tidak dapat membatalkan Putusan Arbitrase Internasional, sedangkan Putusan Arbitrase yang dibuat di dalam negeri hanya dapat dibatalkan dengan melihat peryaratan limitatif dalam Pasal 70 UU No. 30 Tahun 1999.

\footnotetext{
${ }^{37}$ Lihat Pasal.70 UU No. 30 Tahun 1999

38 Penjelasan UU No. 30 Tahun 1999 tentang Arbitrase dan Alternatif Penyelesaian Sengketa, psl. 70;

${ }^{39}$ Lihat Pasal 71 UU No. 30 Tahun 1999

${ }^{40}$ Ibid, Pasal 72 angka (1) dan 72 angka (2)
} 
Majelis Hakim Pengadilan Negeri Jakarta Pusat berpendapat bahwa secara prinsip hanya Pasal VI jo. V (1) (e) Konvensi New York 1958 yang menyatakan Pengadilan yang memiliki wewenang (competent authority) untuk memutus permohonan pembatalan putusan arbitrase adalah Pengadilan di negara mana putusan tersebut dibuat atau Pengadilan berdasarkan hukum mana putusan tersebut dibuat. Kewenangan Pengadilan Negeri Jakarta Pusat hanya berdasarkan interpretasi kedua "sebagai pengadilan berdasarkan hukum mana putusan arbitrase dibuat", 41 padahal semenjak proses arbitrase di Mahkamah Agung Swiss dan pengadilan Texas mencerminkan bahwa kedua belah pihak setuju bahwa "competent authority" yang dimaksud dalam Pasal V (1) (e) Konvensi New York adalah Pengadilan Federal Swiss.

Interpretasi "competent authority" dari Pasal V (1) (e) Konvensi New York 1958 hanya merujuk pada satu otoritas yang berwenang (one competent authority). Hanya ada satu Pengadilan yang berwenang dalam membatalkan putusan arbitrase internasional yaitu Pengadilan dimana putusan arbitrase dibuat. ${ }^{42}$

Ada tiga jenis hukum yang berlaku dan terkait dengan proses arbitrase, yaitu:43

1. Hukum Materiil (substantive law)

Hukum ini degunakan para arbiter untuk memutus perkara. Hukum materiil ini bisa ditentukan oleh para pihak yang bersengketa dalam kontrak yang umumnya dikenal dengan istilah Governing Law, atau apabila tidak disepakati oleh para pihak maka akan ditentukan oleh arbiter.

2. Hukum Acara (procedural law/crurial law) Hukum prosedural ini mengikat bagi para arbiter dan para pihak dalam proses pemeriksaan hingga adanya putusan.

3. Lex Arbitri

Lex Arbitri yaitu hukum dari suatu negara yang mendasari penyelesaian sengketa melalui arbitrase.

Putusan PN Jakarta Pusat sangat tidak konsisten dengan ketiga jenis hukum tersebut dengan menunjukkan tidak adanya pembedaan secara terpisah antara substantive law dan Lex Arbitri. Padahal pembedaan dari kedua hukum ini sangat penting dalam konteks hukum arbitrase internasional. Setiap negara mempunyai

${ }^{41}$ Dodik Setiawan Nur Heriyanto, Op. Cit., hlm. 8-9, sebagaimana dikutip dari Bermann, Competence to Set Aside An Award and Procedural Grounds for Refusing Enforcement: the Viewpoint and Role of Arbitration Law Expert, 3Am.Rev.Int'l.Arb. 1992, hlm. 93.

${ }^{42}$ Hikmahanto Juwana, "Pembatalan Putusan Arbitrase Internasional oleh Pengadilan Nasional", Jurnal Hukum Bisnis, Vo. 21, Jakarta, 2002, hlm. 71.

${ }^{43}$ Ibid., hlm. 69. 
Lex Arbitri masing-masing. Dan Lex Arbitri sangat erat kaitannya dengan "seat" yaitu negara dimana tempat arbtrase dilaksanakan. ${ }^{4}$

Beberapa contoh kaitan antara "seat" dengan Lex Arbitri ini misalnya saja apabila para pihak menentukan "seat" mereka di ICC Paris maka Lex Arbitri nya adalah hukum Perancis. Dan jika para pihak menentukan tempat arbitrase mereka di Singapore International Center, maka Lex Arbitri yang dipakai adalah hukum Singapura. Apalagi ketika para pihak menentukan tempat arbitrase mereka di Badan Arbitrase Nasional Indonesia, maka Lex Arbitri yang dipakai adalah hukum Indonesia. Sehingga dapat disimpulkan apabila KBC dan Pertamina telah menentukan "seat" di Arbitrase Jenewa, maka Lex Arbitri yang dipakai adalah hukum negara Swiss.

Sebagai bentuk perlawanan terhadap putusan PN Jakarta Pusat, pihak Karaha Bodas mengajukan kasasi ke Mahkamah Agung. Salah satu butir memori kasasinya mengatakan bahwa Majelis Hakim Pengadilan Negeri Jakarta Pusat dinilai tidak bisa membedakan antara pembatalan dan penolakan pelaksanaan putusan arbitrase internasional. ${ }^{45}$

Dalam kasus Pertamina v. KBC yang diajukan pembatalannya kepada PN Jakarta Pusat terdaftar No.86/Pdt.G/2002/PN.JKT PST dan telah diputus, maka dalam proses pemeriksaan banding di MA, dengan Putusan No. 01/Banding/ Wasit.Int/2002, 8 Maret 2004 Majelis Hakim Agung memberikan beberapa pertimbangan yang intisarinya adalah sebagai berikut: (1) Mengenai Arbitrase Internasional, Undang-Undang No. 30 Tahun 1999 hanya mengaturnya dalam Pasal 65 s/d Pasal 69 yang selain mengatur syarat-syarat dapat diakui dan dilaksanakannya suatu putusan Arbitrase Internasional di Indonesia, juga mengatur prosedur permohonan pelaksanaan putusan arbitrase tersebut; (2) Pasal V ayat (1) e Konvensi New York 1958 telah disahkan dan dinyatakan berlaku dengan Keputusan Presiden No. 34 Tahun 1981; (3) Kuasa Hukum Pertamina dan PLN telah mengajukan permohonan banding terhadap putusan arbitrase yang disengketakan kepada Mahkamah Agung Swiss sesuai dengan Undang-Undang Hukum Perdata Internasional Negara Swiss. (4) Oleh karena itu Pengadilan Negeri Jakarta Pusat tidak berwenang untuk memeriksa dan memutus gugatan pembatalan putusan Arbitrase Internasional yang diajukan oleh Penggugat. ${ }^{46}$

Amar Putusan Mahkamah Agung menyatakan bahwa Pengadilan Negeri Jakarta Pusat tidak berwenang untuk memeriksa dan memutus gugatan

${ }^{44}$ Hikmahanto Juwana, Loc. Cit.

45 Karaha Bodas Ajukan Kasasi terhadap Putusan Pembatalan Arbitrase Jenewa, lihat http://www.hukumonline.com/detail.asp?id=6528\&cl=Berita, diakses pada tanggal 10 Agustus 2017 pukul 19.45.

46 Putusan Mahkamah Agung Republik Indonesia, No. 01/BANDING/WASIT-INT/2002, tanggal 8 Maret 2004. 
pembatalan "Putusan Arbitrase Internasional". Oleh karena itu, Majelis Hakim Agung menilai bahwa putusan arbitrase diputus oleh para arbiter di negara Swiss, maka gugatan pembatalannya seharusnya diajukan ke Swiss Federal Court.

\section{Penutup}

Perdagangan internasional sangat baik untuk dilakukan apabila hubungan bilateral baik antar negara atau pelaku usaha dari setiap negara berjalan dengan baik. Semua unsur dalam perdagangan internasional itu nantinya dapat terpenuhi dengan baik sehingga tercipta iklim perdagangan yang baik juga. Dari uraian di atas penulis dapat menarik kesimpulan bahwa putusan arbitrase internasional bersifat final dan mengikat para pihak. Terhadap putusan ini masih dapat dimungkinkan dilakukan dua upaya hokum, yaitu penolakan dan pembatalan pelaksanaan arbitrase asing. Kedua upaya hukum ini mempunyai dua implikasi yang berbeda dalam pelaksanaan putusan arbitrase internasional. Munculnya dua upaya hukum pembatalan putusan arbitrase Jenewa baik di Swiss Federal Court dan Pengadilan Negeri Jakarta Pusat menimbulkan banyak perdebatan mengenai pengadilan mana yang berwenang dalam pembatalan putusan arbitrase Jenewa. Dengan ditunjuknya Jenewa sebagai place of arbitration (seat) dan hukum yang mendasari penyelesaian sengketa arbitrase (Lex Arbitri), maka yang berwenang untuk membatalkan putusan arbitrase Jenewa adalah Swiss Federal Court. Dengan demikian, Pengadilan Negeri Jakarta Pusat tidak berwenang untuk mengadili upaya pembatalan putusan arbitrase Jenewa.

\section{Daftar Pustaka}

\section{Buku}

Adolf, Huala, Hukum Penyelesaian Sengketa Internasional, Cetakan Pertama, Sinar Grafika, Jakarta, tt.

Bossche, Peter van den, Pengantar Hukum WTO (World Trade Organization), Yayasan Obor Indonesia, Jakarta, 2010.

Fuady, Munir, Hukum Dagang Internasional (Aspek Hukum dari WTO), Citra Aditya Bakti, Bandung, 2004.

Fuady, Munir, Arbitrase (Alternatif Penyelesaian Sengketa Bisnis), Citra Aditya Bakti, Bandung, 2000.

Gautama, Sudargo, Masalah-masalah Perdagangan, Perjanjian, Hukum Perdata Internasional Dan Hak Milik Intelektual, Cetakan Pertama, Citra Aditya Bakti, Bandung, 1992. 
Gautama, Sudargo, Perkembangan Arbitrase Dagang Internasional di Indonesia, Eresco, Jakarta, 1989. Sudargo Gautama, Arbitrase Luar Negeri dan Pemakaian Hukum Indonesia, PT. Citra Adhitya Bakti, Bandung, 2004.

Harahap, M. Yahya, Arbitrase ditinjau dari Reglemen Acara Perdata (Rv), Peraturan Prosedur BANI, International Centre for the Settlement of Investment Disputes (ICSID), UNCITRAL Arbitration Rules, Convention on the Recognition and Enforcement of Foreign Arbitral Award, dan Perma No. 1 Tahun 1990, Edisi Kedua, Sinar Grafika, Jakarta, 2006.

Hartono, Sunarjati, Beberapa Masalah Transnasional dalam Penanaman Modal Asing di Indonesia, Cet.ke-1, Binacipta, Bandung, 1972.

Ichsan, Akhmad, Kompedium Tentang Arbitrase Perdagangan Internasional (Luar Negeri), Cetakan Pertama, Pradnya Paramita, Jakarta, tt.

Subekti, Kitab Undang-Undang Hukum Perdata, Pradnya Paramita, Jakarta, 1981.

Sukarmi, Regulasi Antidumping di Bawah Byang-bayang Bebas, Sinar Grafika, Jakarta, 2002.

\section{Jurnal / Warta Hukum}

Heriyanto, Dodik Setiawan Nur, "Pembatalan Keputusan Arbitrase Internasional Oleh Pengadilan Negeri (Studi Kasus Pembatalan Keputusan Arbitrase Jenewa oleh Pengadilan Jakarta Pusat)", Warta Hukum Edisi Juli-Agustus, Pusdiklat FH UII, Yogyakarta, 2009.

Heriyanto, Dodik Setiawan Nur, "Strengthening Indonesian Judges Understanding of the Refusal and Annulment Grounds of Foreign Arbitral Awards", Acta Juridica Hungarica, Vol. 56, 2015.

Hikmahanto Juwana, "Pembatalan Putusan Arbitrase Internasional oleh Pengadilan Nasional", Jurnal Hukum Bisnis, Vo. 21, Jakarta, 2002.

\section{Internet}

Harry Katuuk, Kekalahan Pertamina vs Karaha Bodas CO Dalam Peradilan Arbitrase Internasional, pada http://www.google.com, diakses pada 10 Agustus 2017

Karaha Bodas Ajukan Kasasi terhadap Putusan Pembatalan Arbitrase Jenewa, lihat http://www.hukumonline.com/detail.asp?id=6528\&cl=Berita, diakses pada 10 Agustus 2017

Muhammad Asri, http://www.anaksmanda.com/PENYELESAIAN SENGKETA/ arbitrase-internasional.html, diakses pada 10 Agustus 2017

\section{Peraturan Perundang-Undangan}

Undang-Undang Nomor 30 Tahun 1999 Tentang Arbitrase dan Alternatif Penyelesaian Sengketa, Lembaran Negara Tahun 1999, Tambahan Lembaran Negara RI Nomor 3872

Keputusan Presiden Nomor 34 Tahun 1981 Tentang mengesahkan "Convention On The Recognition And Enforcement Of Foreign Arbitral Awards", Yang Telah Ditandatangani Di New York Pada Tanggal 10 Juni 1958 Dan Telah Mulai Berlaku Pada Tanggal 7 Juni 1959 
Convention on the Recognition and Enforcement of Foreign Arbitral Awards, 10 Juni 1958, 330 U.N.T.S. 38., psl.II(3).

\section{Putusan Pengadilan}

Putusan Pengadilan Jakarta Pusat, No. 86/PN/Jkt.Pst/2002, 9 September 2002.

Putusan Mahkamah Agung Republik Indonesia, No. 01/BANDING/WASITINT/2002, 8 Maret 2004. 